\title{
Single-stranded DNA
}

National Cancer Institute

\section{Source}

National Cancer Institute. Single-stranded DNA. NCI Thesaurus. Code C111311.

A long linear single-stranded polymer formed from nucleotides attached to a deoxyribose backbone. 